\title{
Tree species richness and turnover throughout New Zealand forests
}

\author{
Bellingham, P.J. ${ }^{{ }^{*}}$, Stewart, G.H. ${ }^{2} \&$ Allen, R.B. ${ }^{1}$ \\ ${ }^{1}$ Landcare Research, P.O. Box 69, Lincoln, New Zealand; \\ ${ }^{2}$ Soil, Plant \& Ecological Sciences Division, Lincoln University, P.O. Box 84, Lincoln, New Zealand; \\ *Corresponding author; Fax +64 3325 2418; E-mail bellinghamp@landcare.cri.nz
}

\begin{abstract}
Patterns of mortality, recruitment, and forest turnover were investigated using permanent plot data from temperate forests in 14 localities throughout New Zealand. Tree mortality and recruitment rates were calculated from tagged trees $\geq 10 \mathrm{~cm}$ diameter at $1.4 \mathrm{~m}$ on individual $400 \mathrm{~m}^{2}$ plots, and turnover rates were calculated as the mean of mortality and recruitment rates. Turnover rates (1.4\% per year) were very similar to those recorded for tropical forests (i.e. $1.5 \%$ per year). As was shown in tropical forests, we also found significant relationships between forest turnover and species richness. In New Zealand forests there was also a decrease in species richness and turnover rates with increasing latitude. Although species richness is well known to decline with latitude, our study provides support for a possible link between seasonality and disturbance with tree turnover and species diversity. While tree mortality and recruitment rates were approximately in balance at some localities, in others there were imbalances between mortality and recruitment rates.
\end{abstract}

Keywords: Browsing mammal; Disturbance; Latitude; Mortality; Recruitment; Temperate forest.

Nomenclature: Allan (1961); King (1990).

\section{Introduction}

In tropical rain forests, diversity (as measured by species richness) was found by Phillips et al. (1994) to be positively correlated with tree turnover rates, i.e. the average of tree mortality and recruitment rates. They considered that forests with higher turnover, and higher diversity, were those subject to more frequent fine-scale disturbance. It is unknown whether the relationship between species richness and turnover rates found by Phillips et al. (1994) applies in less species-rich temperate forests. If there is a positive relationship between turnover rates and species richness in temperate forests, we might also expect a negative correlation between turnover rates and latitude, since there is generally a decrease in species richness of forests with increasing latitude (e.g. Currie \& Paquin 1987). Correlations of geographic patterns in turnover and species richness with those environmental variables that change with latitude do not provide a mechanistic explanation for observed patterns (Huston 1999). Recently, Givnish (1999) proposed that tree turnover should decrease with increas- ing latitude due to increasing seasonality; this produces conditions less favourable to abundance of natural plant enemies, i.e. insects and fungi which, at low latitudes, cause more frequent tree death. If such geographic, or environmental, patterns in turnover exist, they may represent a mechanistic link to species diversity patterns resulting from disturbance.

Tree mortality and recruitment are also influenced by many forms of disturbance, both natural and humaninduced (Pickett \& White 1985). After intensive disturbance, forest development often includes periods of self-thinning, in stands with high stem density and/or basal area, where high mortality rates and low recruitment rates are apparent (Waring \& Schlesinger 1985). Disparities between mortality and recruitment rates, as a result of disturbance, can also be pronounced at an individual species level (Harcombe 1987). For example, during succession after disturbance there are often high mortality rates and low recruitment rates of early successional species and the converse for late successional species (Veblen 1992).

In this paper, we investigate whether there are relationships between forest turnover rates and tree species richness in New Zealand's temperate rain forests. We also test whether forest turnover, or tree species richness are related to latitude. These relationships are tested using tree census data from permanent plots sampling 14 localities throughout New Zealand. Forests at some localities included in this study are subject to 'dieback' events (sensu Mueller-Dombois et al. 1983) resulting from natural or human-induced disturbance (e.g. Grant 1963; Pekelharing \& Reynolds 1983; Ogden et al. 1993). In these forests, we examine whether there are imbalances between mortality and recruitment rates, and compare the resulting turnover rates with those of forests without 'dieback' elsewhere. Although turnover rates among all species allow comparisons among compositionally and structurally different forests, individual species responses are needed to determine coexistence mechanisms and successional changes (Kohyama 1993; Condit et al. 1995). Because many New Zealand tree species are widespread (Meurk 1995), we are also able to test whether there are imbalances in mortality $v s$. recruitment for individual species at different localities. 


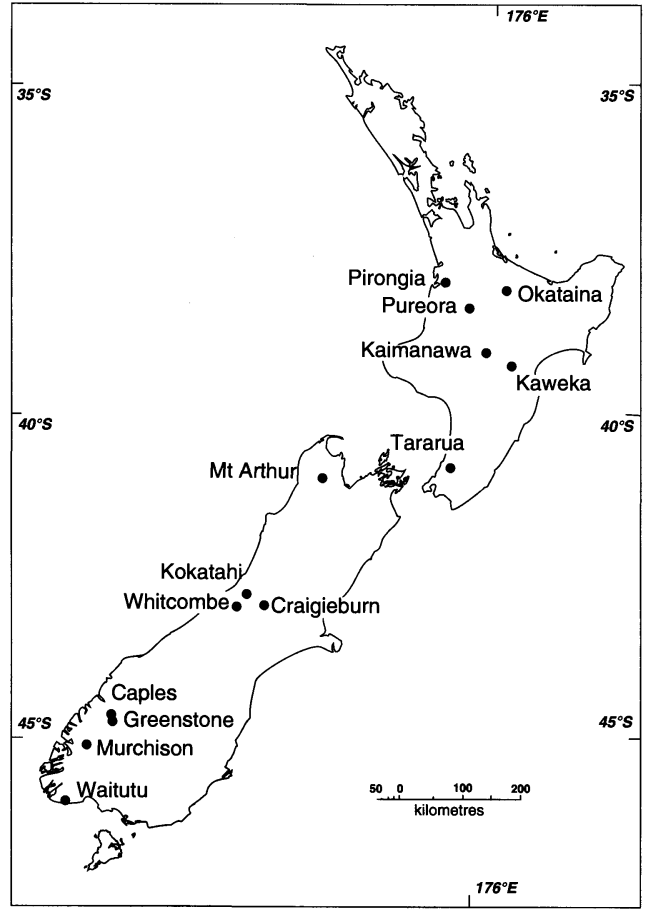

Fig. 1. 14 localities in New Zealand with long-term $(\geq 8 \mathrm{yr})$ census data from permanent forest plots.

\section{Methods}

We determined forest turnover rates on plots from 14 localities covering more than $8^{\circ}$ latitude (Fig. 1) and a range of underlying lithology, soils, and forest types (Table 1). Broad forest types were defined for each locality according to the basal area dominance, across all plots, in a locality of: conifers; angiosperm trees other than Nothofagus ('hardwoods'); and Nothofagus species, which often dominate stands (Ogden et al. 1996). All localities have at least 8 years of census data (maximum $=$ $27 \mathrm{yr}$ ), sampled with various numbers of permanent $20 \mathrm{~m}$ $\times 20 \mathrm{~m}$ plots located along compass lines (see Allen 1993). The origin of each line, in each locality, was located along a stream course in a restricted random fashion. Plots were then located at $200 \mathrm{~m}$ intervals along these compass lines, except in Kokatahi and Whitcombe where plots were located at regular altitudinal intervals, thus at each locality the plots can be used to portray the average dynamics of the forests. Within each plot, all stems $\geq 10 \mathrm{~cm}$ diameter at $1.4 \mathrm{~m}$ height ( $\mathrm{dbh}$ ) were tagged at measurement height at the earliest census, mortality of tagged stems noted at later censuses, and ingrowth stems (i.e., stems that grew to become $\geq 10 \mathrm{~cm} \mathrm{dbh}$ ) were tagged at later censuses.

Summaries of numbers of stems for each plot at each census were derived from Hall (1994). We calculated a mortality rate for all species combined in each plot as an annual percentage of the initial stems using a logarithmic model (McCune \& Cottam 1985; Sheil et al. 1995), and calculated a recruitment rate above the minimum size (10 $\mathrm{cm} \mathrm{dbh)} \mathrm{for} \mathrm{each} \mathrm{plot} \mathrm{as} \mathrm{an} \mathrm{annual} \mathrm{percentage} \mathrm{according}$ to a similar logarithmic model (modified from McCune and Cottam 1985). Turnover rates per plot were defined as the mean of mortality and recruitment rates (after Phillips \& Gentry 1994). Species richness was calculated for each plot as the number of species $\geq 10 \mathrm{~cm} \mathrm{dbh} / 400$ $\mathrm{m}^{2}$, after Phillips et al. (1994). We also computed a Shannon-Wiener index for each plot using stems $\geq 10 \mathrm{~cm}$ $\mathrm{dbh}\left(H^{\prime}\right.$, a frequently used measure of species diversity as well as dominance; e.g. Magurran 1988; Tilman et al. 1996). Stem density and basal area (all of stems $\geq 10 \mathrm{~cm}$ $\mathrm{dbh}$ at the most recent census) were calculated for each plot as surrogates for stand development following disturbance (Harper 1977). We examined relationships between the three demographic rates (i.e. mortality, recruitment and turnover rates), latitude, species richness and diversity, as well as stem density and basal area as variables for each plot using generalised linear models (GLMs, Crawley 1993), with variables nested within localities. We also related the mean of the demographic rates per locality with the mean altitude and mean annual rainfall of the localities using Spearman's rank correlations. Demographic rates were compared between localities for four widespread common tree species, i.e. Nothofagus menziesii and Nothofagus solandri var. cliffortioides (both Fagaceae), Podocarpus hallii (Podocarpaceae), and Weinmannia racemosa (Cunoniaceae). Demographic rates were also compared for each species with the mean proportion each comprised of total stem density and total basal area. For individual species analyses, the total number of stems of each species was aggregated across all plots at a locality, and demographic rates computed across all plots.

All percentage data were arcsine square-root transformed for analysis. Generalised linear models were conducted in S-Plus version 4.0 (Anon. 1997). Spearman's rank correlations $\left(r_{\mathrm{S}}\right)$ and ANOVA tests were conducted using SYSTAT version 7.0 (Wilkinson 1997).

\section{Results}

\section{All species combined}

Across all plots, there were significant negative relationships of latitude with tree mortality, recruitment and turnover rates (GLMs, $F_{14,659}=1.84,1.89$ and 2.39 respectively, all $P<0.05$, Fig. 2 ). Mortality, recruitment and turnover rates were also significantly different between the 14 localities (GLMs, $F_{13,673}=9.82,22.25$ and 16.33 respectively, all $P<0.01$, Table 2 ). 
Table 1. Site details of forests in various localities in New Zealand.

\begin{tabular}{|c|c|c|c|c|c|c|}
\hline Locality & Forest type & Latitude, Longitude & Lithology & Soils* & $\begin{array}{c}\text { Elevation } \\
\text { mean }(\mathrm{m}), \text { (range) }\end{array}$ & $\begin{array}{c}\text { Rainfall } \\
(\mathrm{mm}) \dagger\end{array}$ \\
\hline Pirongia & Hardwood & $37^{\circ} 59^{\prime} \mathrm{S}, 175^{\circ} 02^{\prime} \mathrm{E}$ & Basalt & Dystrochrepts & $470(200-760)$ & 1600 \\
\hline Okataina & Hardwood-conifer & $38^{\circ} 08^{\prime} \mathrm{S}, 176^{\circ} 27^{\prime} \mathrm{E}$ & Recent volcanic tephras & Udorthents & $480(320-800)$ & 2060 \\
\hline Pureora & Hardwood-conifer & $38^{\circ} 23^{\prime} \mathrm{S}, 175^{\circ} 35^{\prime} \mathrm{E}$ & Ignimbrite & Vitric hapludands & $530(350-850)$ & 1770 \\
\hline Kaimanawa & $\begin{array}{l}\text { Mixed Nothofagus- } \\
\text { hardwood }\end{array}$ & $39^{\circ} 03^{\prime} \mathrm{S}, 175^{\circ} 58^{\prime} \mathrm{E}$ & $\begin{array}{l}\text { Greywacke overlain } \\
\text { with volcanic ash }\end{array}$ & $\begin{array}{l}\text { Vitric hapludands and } \\
\text { vitrandric dystrochrepts }\end{array}$ & $860(240-1210)$ & 1530 \\
\hline Kaweka & $\begin{array}{l}\text { Nothofagus } \\
\text { (mono-dominant) }\end{array}$ & $39^{\circ} 15^{\prime} \mathrm{S}, 176^{\circ} 25^{\prime} \mathrm{E}$ & Greywacke & $\begin{array}{l}\text { Vitrandric } \\
\text { dystrochrepts }\end{array}$ & $1180(920-1400)$ & 1580 \\
\hline Tararua & $\begin{array}{l}\text { Mixed Nothofagus- } \\
\text { hardwood }\end{array}$ & $41^{\circ} 00^{\prime} \mathrm{S}, 175^{\circ} 13^{\prime} \mathrm{E}$ & Greywacke/Argillite & Dystrochrepts & $720(530-1080)$ & 2750 \\
\hline Mt. Arthur & Mixed Nothofagus & $41^{\circ} 11^{\prime} \mathrm{S}, 172^{\circ} 38^{\prime} \mathrm{E}$ & Limestone & Endoaquepts & $1160(1080-1270)$ & 2400 \\
\hline Kokatahi & Hardwood-conifer & $42^{\circ} 57^{\prime} \mathrm{S}, 171^{\circ} 12^{\prime} \mathrm{E}$ & Schist & Humaquepts and endoaquepts & $590(320-780)$ & $6000-8000$ \\
\hline Whitcombe & Hardwood-conifer & $43^{\circ} 05^{\prime} \mathrm{S}, 171^{\circ} 01^{\prime} \mathrm{E}$ & Schist & Humaquepts and endoaquepts & $560(250-850)$ & 8090 \\
\hline Craigieburn & $\begin{array}{l}\text { Nothofagus } \\
\text { (mono-dominant) }\end{array}$ & $43^{\circ} 10^{\prime} \mathrm{S}, 171^{\circ} 35^{\prime} \mathrm{E}$ & Greywacke/Argillite & Dystrochrepts & $1050(640-1420)$ & $1400-2500$ \\
\hline Caples & $\begin{array}{l}\text { Mixed Nothofagus } \\
\text { - conifer }\end{array}$ & $44^{\circ} 52^{\prime} \mathrm{S}, 168^{\circ} 13^{\prime} \mathrm{E}$ & $\begin{array}{l}\text { Greywacke/Argillite/ } \\
\text { Siltstones }\end{array}$ & Dystrochrepts & $680(290-1140)$ & 2300 \\
\hline Greenstone & Mixed Nothofagus & $44^{\circ} 57^{\prime} \mathrm{S}, 168^{\circ} 15^{\prime} \mathrm{E}$ & $\begin{array}{l}\text { Greywacke/Argillite/ } \\
\text { Siltstones }\end{array}$ & Dystrochrepts & $750(290-1140)$ & 2300 \\
\hline Murchison & $\begin{array}{l}\text { Mixed Nothofagus- } \\
\text { - hardwood }\end{array}$ & $45^{\circ} 18^{\prime} \mathrm{S}, 167^{\circ} 38^{\prime} \mathrm{E}$ & Gneiss and granite & Dystrochrepts & $690(210-1090)$ & $2400-4500$ \\
\hline Waitutu & $\begin{array}{l}\text { Mixed Nothofagus- } \\
\text { hardwood-conifer }\end{array}$ & $46^{\circ} 12^{\prime} \mathrm{S}, 167^{\circ} 04^{\prime} \mathrm{E}$ & $\begin{array}{l}\text { Sedimentaries and } \\
\text { alluvium (glacial } \\
\text { outwash and marine) }\end{array}$ & $\begin{array}{l}\text { Haplorthods and } \\
\text { dystrochrepts }\end{array}$ & $260(3-890)$ & 1160 \\
\hline
\end{tabular}

* Soil classifications follow US Department of Agriculture (Anon. 1998).

† Rainfall estimates are from the nearest rainfall station (Anon. 1973) for all localities except Kokatahi (estimated from Griffiths \& McSaveney 1983), Whitcombe (data from Griffiths \& McSaveney 1983), Craigieburn (data from Harcombe et al. 1998) and Murchison (data from two rainfall stations in the study area, W.G. Lee, pers. comm.).

Both species richness and species diversity (Shannon-Wiener $H^{\prime}$ ) declined with latitude (GLMs, $F_{14,659}=$ 5.75 and 4.67 respectively, both $P<0.01$ ), and were highly significantly different between localities (GLMs, $F_{13,673}=133.55$ and 149.96 respectively, both $P<$ 0.001 , Table 2). Species richness and diversity declined with increasing mean altitude of localities $\left(r_{\mathrm{S}}=-0.81\right.$ and -0.78 respectively, both $P<0.002$ ), but were not significantly correlated with mean rainfall of localities $\left(r_{\mathrm{S}}=0.02\right.$ and 0.01 respectively, both $\left.P>0.1\right)$.

Across all localities, there were positive relationships between tree mortality, recruitment and turnover rates and species richness (GLMs, $F_{14,659}=2.30,2.01$ and 2.05 respectively, all $P<0.025$, Fig. 3), and species diversity $\left(H^{\prime}\right)$ (GLMs, $F_{14,659}=2.60,2.32$ and 2.56 respectively, all $P<0.01$, Fig. 4).

Across all plots, tree mortality, recruitment and turnover rates of all species combined were highest when total stem density was lowest (Table 2, GLMs, $F_{14,659}=$ $3.09,1.97$ and 2.59 respectively, all $P<0.025$ ). Similarly, tree mortality, recruitment and turnover rates of all species combined declined with increasing plot basal area (Table 2, GLMs, $F_{14,659}=5.38,3.41$ and 6.95 respectively, all $P<0.01)$. Species richness increased with increasing stem density and plot basal area (GLMs, $F_{14,659}=5.45$ and 2.39 respectively, both $P<0.01$ ). Likewise, species diversity $\left(H^{\prime}\right)$ increased with increasing stem density and plot basal area (GLMs, $F_{14,659}=$ 4.52 and 2.25 respectively, both $P<0.025$ ).

In most localities, mortality and recruitment rates

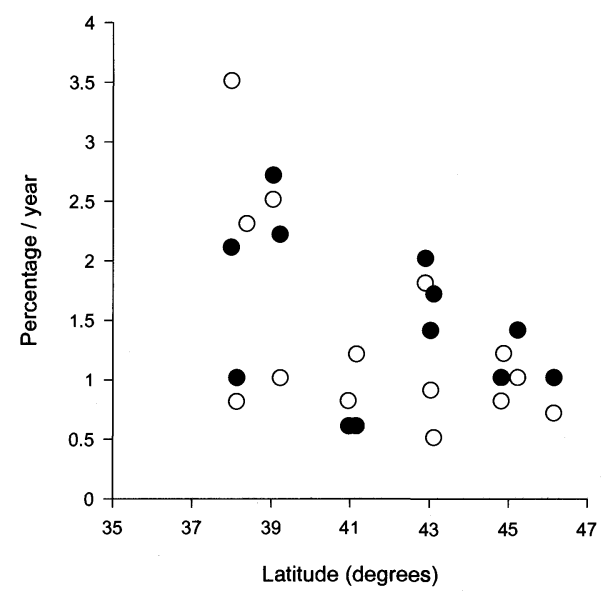

Fig. 2. Mean mortality rates $(0)$ and recruitment rates $(O)$ of tree stems $\geq 10 \mathrm{~cm} \mathrm{dbh}$ in permanent forest plots in 14 localities in New Zealand vs latitude. 


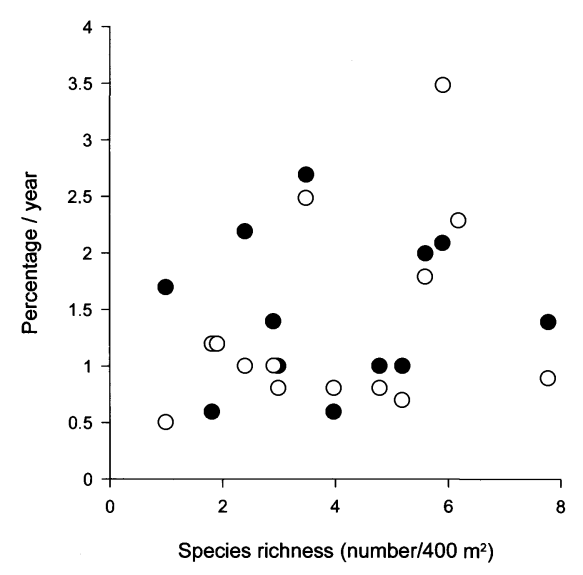

Fig. 3. Mean mortality rates (O) and recruitment rates $(O)$ of tree stems $\geq 10 \mathrm{~cm}$ dbh $v s$ mean species richness (number of species $\geq 10 \mathrm{~cm} \mathrm{dbh}$ ) in permanent forest plots in 14 localities in New Zealand.

were similar, i.e. $<0.5 \% / y r$ difference between the two rates (Table 2). The greatest differences between mortality and recruitment rates were in Craigieburn (high altitude mono-dominant Nothofagus solandri var. cliffortioides forests), where mortality rates exceeded recruitment rates by $1.1 \% / y r$, and in Pirongia (hardwood forests), where recruitment rates exceeded mortality rates by $1.3 \% / y r$. There was no consistent pattern of discrepancies (i.e. positive or negative differences between mortality and recruitment rates) that related to species richness or diversity, latitude, altitude or rainfall of localities, or mean plot stem density or basal area $\left(r_{\mathrm{S}}\right.$ all $<0.38$, all $P>0.1$.

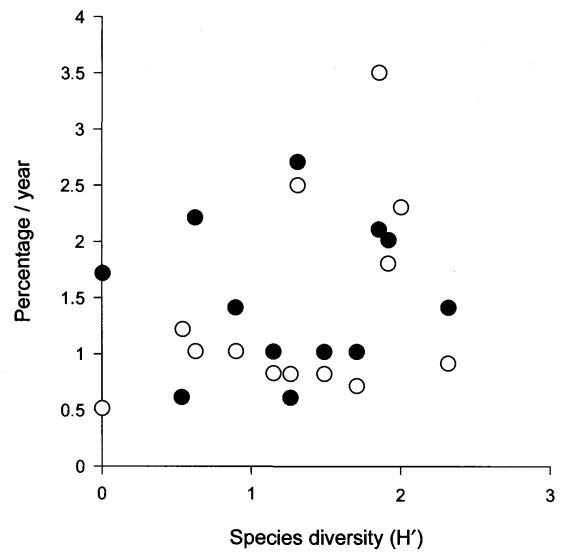

Fig. 4. Mean mortality rates (O) and recruitment rates (O) of tree stems $\geq 10 \mathrm{~cm}$ dbh $v s$ mean species diversity (ShannonWiener $H^{\prime}$, calculated on stems $\geq 10 \mathrm{~cm}$ dbh per species) in permanent forest plots in 14 localities in New Zealand.

\section{Individual species}

Across all localities present, the mean recruitment rates of the conifer Podocarpus hallii ( $\bar{x}=0.4 \pm 0.2 \%$ l yr) were significantly lower than those of the three angiosperm species (Nothofagus solandri var. cliffortioides: $0.9 \pm 0.1 \% / \mathrm{yr}$; Nothofagus menziesii: $1.1 \pm 0.19 \% /$ yr; Weinmannia racemosa: $1.4 \pm 0.28 \% / \mathrm{yr}$; Table 3, ANOVA, $P=0.01$ ). Mortality and turnover rates were not different among the four species (Table 3, ANOVA, $P>0.05)$. Mortality rates of $W$. racemosa exceeded recruitment rates by $4.8 \% / y r$ in Pureora, but in Pirongia and Kaimanawa recruitment rates of $W$. racemosa ex-

Table 2. Species diversity and richness as well as mortality, recruitment and turnover rates of trees $\geq 10 \mathrm{~cm}$ dbh in forests at various localities in New Zealand.

\begin{tabular}{|c|c|c|c|c|c|c|c|c|c|c|}
\hline Locality & $\begin{array}{l}\text { No. of plots } \\
\text { and total } \\
\text { area (ha) }\end{array}$ & $\begin{array}{l}\text { Trees/ } \\
400 \mathrm{~m}^{2}\end{array}$ & $\begin{array}{c}\text { Basal area } \\
\left(\mathrm{m}^{2} /\right. \\
\left.400 \mathrm{~m}^{2}\right)\end{array}$ & $\begin{array}{c}\text { Diversity } \\
\text { index } \\
\left(H^{\prime}\right)\end{array}$ & $\begin{array}{l}\text { Species } \\
\text { richness } \\
\text { (species/ } \\
400 \mathrm{~m}^{2} \text { ) }\end{array}$ & $\begin{array}{c}\text { Time } \\
\text { (years) }\end{array}$ & $\begin{array}{l}\text { Inventory } \\
\text { period }\end{array}$ & $\begin{array}{l}\text { Mortality } \\
\text { rate } \\
(\% / y r)\end{array}$ & $\begin{array}{c}\text { Recruit- } \\
\text { ment rate } \\
(\% / y r)\end{array}$ & $\begin{array}{c}\text { Turn- } \\
\text { over rate } \\
(\% / y r)\end{array}$ \\
\hline Pirongia & $20(0.80)$ & 29.1 & 1.55 & 1.87 & 5.9 & 8 & $1979-1987$ & 2.1 & 3.5 & 2.8 \\
\hline Okataina & $36(1.44)$ & 46.3 & 1.92 & 1.50 & 4.8 & 8.7 & 1983-1992 & 1.0 & 0.8 & 0.9 \\
\hline Pureora & $28(1.12)$ & 27.1 & 1.47 & 2.02 & 6.2 & 18.7 & $1975-1993$ & 2.3 & 2.3 & 2.3 \\
\hline Kaimanawa & $40(1.60)$ & 16.0 & 2.68 & 1.32 & 3.5 & 8.6 & $1979-1988$ & 2.7 & 2.5 & 2.6 \\
\hline Kaweka & $30(1.20)$ & 31.0 & 1.56 & 0.63 & 2.4 & 13.9 & 1981-1995 & 2.2 & 1.0 & 1.6 \\
\hline Tararua & $10(0.40)$ & 45.8 & 2.66 & 1.26 & 4.0 & 20.8 & $1975-1996$ & 0.6 & 0.8 & 0.7 \\
\hline Mt Arthur & $34(1.36)$ & 47.3 & 2.00 & 0.54 & 1.8 & 8.7 & $1978-1987$ & 0.6 & 1.2 & 0.9 \\
\hline Kokatahi & $22(0.88)$ & 35.6 & 1.96 & 1.93 & 5.6 & 23.2 & $1972-1995$ & 2.0 & 1.8 & 1.9 \\
\hline Whitcombe & $23(0.92)$ & 44.6 & 2.81 & 2.33 & 7.8 & 26.8 & $1972-1999$ & 1.4 & 0.9 & 1.1 \\
\hline Craigieburn & $250(10.00)$ & 41.8 & 1.83 & 0.01 & 1.0 & 19.2 & 1974-1994 & 1.7 & 0.5 & 1.1 \\
\hline Caples & $20(0.80)$ & 20.7 & 2.03 & 1.15 & 3.0 & 21 & 1976-1997 & 1.0 & 0.8 & 0.9 \\
\hline Greenstone & $29(1.16)$ & 27.0 & 2.57 & 0.55 & 1.9 & 13 & 1976-1989 & 1.2 & 1.2 & 1.2 \\
\hline Murchison & $38(1.52)$ & 29.5 & 2.57 & 0.90 & 2.9 & 22.6 & 1976-1998 & 1.4 & 1.0 & 1.2 \\
\hline Waitutu & $107(4.28)$ & 32.0 & 3.03 & 1.72 & 5.2 & 19.1 & $1978-1997$ & 1.0 & 0.7 & 0.9 \\
\hline
\end{tabular}


Table 3. Demographic rates of trees $\geq 10 \mathrm{~cm}$ dbh of four species in forests at various localities in New Zealand. $\mathrm{P}=$ mean percentage each species forms of total stems per plot; $\mathrm{M}=$ mortality rate $(\% / \mathrm{yr}) ; \mathrm{R}=$ recruitment rate $(\% / \mathrm{yr})$; $\mathrm{T}=$ turnover rate (mean of mortality and recruitment rate, $\% / \mathrm{yr}$ ).

\begin{tabular}{|c|c|c|c|c|c|c|c|c|c|c|c|c|c|c|c|c|}
\hline \multirow[t]{2}{*}{ Locality } & \multicolumn{4}{|c|}{$\begin{array}{c}\text { Nothofagus } \\
\text { menziesii }\end{array}$} & \multicolumn{4}{|c|}{$\begin{array}{l}\text { Nothofagus solandri } \\
\text { var. cliffortioides }\end{array}$} & \multicolumn{4}{|c|}{$\begin{array}{l}\text { Podocarpus } \\
\text { hallii }\end{array}$} & \multicolumn{4}{|c|}{$\begin{array}{l}\text { Weinmannia } \\
\text { racemosa }\end{array}$} \\
\hline & $\mathrm{P}$ & $\mathbf{M}$ & $\mathbf{R}$ & $\mathrm{T}$ & $\mathrm{P}$ & $\mathbf{M}$ & $\mathrm{R}$ & $\mathrm{T}$ & $\mathrm{P}$ & $\mathbf{M}$ & $\mathrm{R}$ & $\mathrm{T}$ & $\mathrm{P}$ & $\mathbf{M}$ & $\mathrm{R}$ & $\mathrm{T}$ \\
\hline Pirongia & & & & & & & & & & & & & 38.2 & 1.4 & 2.8 & 2.1 \\
\hline Okataina & & & & & & & & & & & & & 32.0 & 0.8 & 0.3 & 0.5 \\
\hline Pureora & & & & & & & & & & & & & 6.5 & 6.6 & 1.8 & 4.2 \\
\hline Kaimanawa & 55.7 & 2.0 & 2.1 & 2.1 & & & & & & & & & 10.1 & 1.6 & 2.7 & 2.1 \\
\hline Kaweka & & & & & 79.5 & 2.0 & 1.0 & 1.5 & 4.6 & 2.8 & 0.9 & 1.8 & & & & \\
\hline Tararua & 27.8 & 0.3 & 0.7 & 0.5 & & & & & 2.0 & 0.0 & 0.9 & 0.4 & 52.8 & 0.5 & 0.9 & 0.7 \\
\hline Mt Arthur & 46.8 & 0.3 & 1.2 & 0.8 & 51.4 & 1.1 & 1.4 & 1.2 & & & & & & & & \\
\hline Kokatahi & & & & & & & & & 2.8 & 3.1 & 0.0 & 1.5 & 24.2 & 1.0 & 0.9 & 1.0 \\
\hline Whitcombe & & & & & & & & & 9.2 & 1.4 & 0.2 & 0.8 & 27.9 & 0.6 & 0.8 & 0.7 \\
\hline Craigieburn & & & & & 99.9 & 1.4 & 0.5 & 0.9 & & & & & & & & \\
\hline Caples & 39.3 & 1.1 & 0.7 & 0.9 & 27.1 & 0.7 & 0.9 & 0.8 & 5.5 & 0.4 & 0.0 & 0.2 & & & & \\
\hline Greenstone & 47.1 & 1.1 & 1.1 & 1.1 & 33.8 & 1.4 & 1.3 & 1.3 & & & & & & & & \\
\hline Murchison & 27.6 & 1.5 & 1.1 & 1.3 & 44.7 & 1.1 & 0.8 & 1.0 & & & & & 9.2 & 1.2 & 1.3 & 1.3 \\
\hline Waitutu & 22.1 & 0.7 & 0.6 & 0.6 & 14.8 & 1.2 & 0.6 & 0.9 & 3.4 & 0.5 & 0.5 & 0.5 & 35.8 & 0.7 & 0.8 & 0.7 \\
\hline
\end{tabular}

ceeded mortality rates by $1.4 \% / y r$ and $1.1 \% / \mathrm{yr}$ (Table 3). For the other six localities in which W. racemosa was common, recruitment and mortality rates were similar. Mortality and recruitment rates of $N$. menziesii were generally similar at most localities, with the greatest discrepancy at Mt Arthur where recruitment rates exceeded mortality rates by $0.9 \% / y r$ (Table 3 ). While recruitment rates of $N$. solandri var. cliffortioides were similar to, or slightly exceeded, its mortality rates in most localities (Table 3), mortality rates of this species greatly exceeded recruitment rates in two montane forests where it was mono-dominant (by $1.1 \% / y r$ in Craigieburn and $1.0 \% / y r$ in Kaweka). Mortality rates of $P$. hallii, a minor component of six forests, were higher than recruitment rates in four localities (Table 3). Most notably, $3.1 \% / y r$ mortality of this conifer in Kokatahi over 23 yr contrasts with nil recruitment over the same period (Table 3), with a less extreme contrast between $0.4 \% / y r$ mortality and nil recruitment over $21 \mathrm{yr}$ in Caples, and a disparity between $2.8 \% / y r$ mortality and $0.9 \% / y r$ recruitment over 14 yr in Kaweka.

Mortality and recruitment rates of $W$. racemosa were greatest when total stem density was lowest $\left(r_{\mathrm{S}}=-0.85\right.$ and -0.87 respectively, both $P<0.01$ ). Mortality rates of $N$. menziesii were also greatest at least total stem density $\left(r_{\mathrm{S}}=-0.86, P<0.05\right.$ ), although its recruitment rates were not significantly correlated with total stem density. Mortality and recruitment rates of $N$. solandri var. cliffortioides and $P$. hallii were not significantly correlated with total stem density $\left(r_{\mathrm{S}}=0.14\right.$ and -0.07 for $N$. solandri var. cliffortioides and -0.14 and 0.29 for $P$. hallii, all $P>0.1)$. For three species $(N$. menziesii, $N$. solandri var. cliffortioides and $P$. hallii) there were no significant correlations between demographic rates and the proportion each species formed of total stems in each locality (Spearman's correlations, all $P>0.1$ ). In the case of $W$. racemosa, there was a weak correlation between mortality rate and the proportion of stems it comprised in a stand $\left(r_{\mathrm{S}}=-0.67, P<0.1\right)$. Mortality and recruitment rates of the four species were not significantly correlated with mean plot basal area in each locality, or with the proportion that each species comprised of the basal area of plots.

\section{Discussion}

The relationship between turnover and species richness found by Phillips et al. (1994) in tropical forests was also apparent in our analyses of data from throughout New Zealand's temperate forests. Within New Zealand, it has long been noted that there is a decline in tree species richness with latitude (Cockayne 1928; Wardle 1991). Productivity is considered by many to decrease with increasing latitude (e.g. Adams \& Woodward 1989), so the additional relationship we found between turnover rates and latitude may in part be related to increasing productivity with decreasing latitude (Givnish 1999), and in our study this trend was evident within some localities and thus may operate a fine scale. However, others (e.g. Huston 1999) consider that productivity increases with increasing latitude. If this is the case, other explanations for decreasing turnover with latitude are needed. One possible explanation for higher turnover rates in New Zealand forests at lower latitudes may be more frequent disturbance. For example, cyclones of tropical origins affect forests at low latitudes more frequently than those at high latitude (Shaw 1983). Such disturbances may cause more frequent mortality of canopy trees in forests at low lati- 
tudes, hence more rapid turnover. The relationship we show between declining tree turnover with increasing latitude (Fig. 2) gives support to the types of mechanisms proposed by Givnish (1999). His explanation for these phenomena are that at high latitudes, conditions are less favourable for pathogens and insects that accelerate rates of tree death, thus mortality rates are lower and hence there is a lower tree species diversity. Lower species diversity in some New Zealand forests is also likely where they have been isolated for millions of years and subjected to repeated local extinctions during glacial periods (McGlone 1988, 1996). An ability to also incorporate these landscape stability processes, as well as turnover, may allow us to explain national-scale diversity patterns more comprehensively (McGlone 1985; Huston 1999).

Contemporary disturbance influences on New Zealand's forests (e.g. drought, cyclones, vulcanism, and earthquakes) are likely to have enduring effects on forest dynamics (Wardle 1991). For example, natural 'diebacks' in high altitude mono-dominant Nothofagus solandri var. cliffortioides forests have occurred in two of the study localities (Wardle 1983, Ogden et al. 1993). Mortality rates exceeded recruitment rates in these forests by $1.1 \% / \mathrm{yr}$ in Craigieburn, and by $0.9 \% / \mathrm{yr}$ in Kaweka; such imbalances between mortality and recruitment rates in forests, and among individual tree species, are often indicative of adjustments to past major disturbances (Nakashizuka 1991). In the case of the two mono-dominant $N$. solandri var. cliffortioides forests, we attribute observed imbalances in mortality and recruitment rates to past disturbance (wind and snow storms and pathogens at Craigieburn, Harcombe et al 1988; drought and pathogens at Kaweka, Hosking \& Hutcheson 1988). Following widespread death of canopy trees there is a lag between mortality and recruitment (Ogden et al. 1993; Harcombe et al. 1998), thus we expect in the future, recruitment rates will exceed mortality rates in these two localities. The range of mortality, recruitment and turnover rates among the $14 \mathrm{New}$ Zealand forests were not different from those at low latitudes in 65 tropical rain forests (Phillips 1996; mortality: $\bar{x}=1.5 \% / \mathrm{yr}$ New Zealand, $1.5 \% / \mathrm{yr}$ tropics; recruitment: $1.4 \% / \mathrm{yr}, 1.6 \% / \mathrm{yr}$; turnover: $1.4 \% / \mathrm{yr}, 1.6 \% /$ yr; unpaired $t$-tests, all $P>0.2$ ). While no attempt was made to remove forests that are subject to major disturbances from the New Zealand dataset, this was attempted in the case of the tropical forest data sets used in Phillips's (1996) analysis.

New Zealand forests are also widely influenced by the impacts of browsing mammals introduced last century (Wardle 1991). Amongst the most widespread introduced animals are brushtail possums (Trichosurus vulpecula), marsupials native to Australia, introduced to
New Zealand in 1858 (Cowan 1990). Brushtail possums selectively browse foliage of certain canopy tree species and have caused tree death in some species (e.g. Meads 1976). Of the four individual species we examined in this study, Weinmannia racemosa and Podocarpus hallii are both common in brushtail possum diets (Fitzgerald 1976; Coleman et al. 1985; Rogers \& Leathwick 1997), and the local mortality of these two species has been attributed to their browsing (e.g. Rose et al. 1992). In contrast, Nothofagus species, including the two species considered in this study, are scarcely represented in the diet of brushtail possums (Wardle 1984; Owen \& Norton 1995). We found no evidence that forests where tree species palatable to brushtail possums predominate, and where brushtail possums have been present for several decades, have consistently higher mortality than forests dominated by the unpalatable Nothofagus species.

Compensatory recruitment of Weinmannia racemosa offset its mortality in all localities in our study except Pureora (Table 3). High turnover of $W$. racemosa was evident in stands of low total stem density. In the Orongorongo forests studied by Campbell (1990), where there was high mortality of $W$. racemosa, it was a minor component of the forests. For the nine localities in our study where $W$. racemosa was common there was a weak negative relationship between its mortality rates and the proportion of total stems contributed by this species. Further data from other localities are required to determine whether there is a relationship between mortality rates of this species and its abundance. While turnover rates across all species are approximately in balance in forests dominated by trees browsed by introduced mammals, those of individual palatable species may not be in balance. For example, whereas mortality and recruitment rates of $W$. racemosa were similar in most localities in our study, this was often not the case for Podocarpus hallii, especially in Kokatahi where high mortality $(3.1 \% / y r)$ and no recruitment over 23 years suggests that it may become locally extinct as a canopy species (cf. Wardle 1978).

During successional change in New Zealand forests where Nothofagus menziesii co- occurs with $N$. solandri var. cliffortioides, Wardle (1983) hypothesised $N$. menziesii would progressively dominate stands as they aged. This expectation would be fulfilled at a locality scale where $N$. menziesii recruitment rates exceed its mortality and where $N$. solandri var. cliffortioides mortality rates exceed its recruitment. In this study, there were three localities where $N$. menziesii and $N$. solandri var. cliffortioides each contributed similar proportions of individuals, and in combination $>70 \%$ of stems (Mt Arthur, Caples and Greenstone, Table 3). At one locality, Mt Arthur, N. menziesii recruitment rates markedly 
exceeded mortality rates, but we did not find the other requirement of $N$. solandri var. cliffortioides mortality rates exceeding recruitment. Therefore we found no evidence from long-term census data of gradual replacement of $N$. solandri var. cliffortioides by $N$. menziesii in mixed stands at a locality scale, and it is more likely to be a process that operates at a finer (plot) scale.

The network of spatially extensive small permanent forest plots in New Zealand (ca. 6500 nationally, mostly established in the 1970s) gives opportunities for understanding long-term changes in forests, both nationally and regionally, in relation to successional trends, withinspecies competitive interactions (Osawa \& Allen 1993) and effects of introduced herbivores (Stewart \& Burrows 1989). The potential is being expanded and realised with the reporting requirements of international agreements (e.g. Convention on Biological Diversity). For example, New Zealand's plot network has been used recently to develop a 1990 estimate of carbon stored in indigenous forests, a requirement of the Framework Convention on Climate Change (Hall et al. 1998). Phillips \& Gentry (1994) showed increasing turnover rates in tropical rain forests with time, and they believed this was a likely consequence of increased atmospheric $\mathrm{CO}_{2}$. New Zealand's national network of permanent plots, in combination with similar networks of plots in other countries, will be able to help evaluation of whether such a phenomenon is true, and, if so, whether it is widespread.

Acknowledgements. We acknowledge the use of information drawn from the National Vegetation Survey (NVS) database. John Wardle had a pivotal role in the design and establishment of plots that contributed to this study. Earliest censuses of the plots and survey design were conducted by staff of the former New Zealand Forest Service and more recent censuses have been conducted by the authors and by staff of, and contractors to, the Department of Conservation and the Wellington Regional Council. We thank Bruce Kyle, Cathy Allan and Wayne Baxter (Department of Conservation) for access to data collected from Caples, Murchison and Waitutu. David Coomes assisted in data analysis. Trevor Webb provided soil classifications for the localities. Kirsty Cullen drafted the figures. We thank Tohru Nakashizuka and Bastow Wilson for helpful comments on the manuscript. GHS received support from the Japanese Ministry of Education, Science and Culture to attend the workshop in Kyoto. This study received financial support from the New Zealand Foundation for Research, Science and Technology (Contract No. CO9633).

\section{References}

Anon. 1973. Rainfall normals for New Zealand 1941 to 1970. New Zealand Meteorological Service, Government Printer, Wellington.

Anon. 1997. S-Plus 4 guide to statistics. Mathsoft Inc., Seattle, WA.
Anon. 1998. Keys to soil taxonomy. 8th ed. United States Department of Agriculture Natural Resources Conservation Service, Washington, DC.

Adams, J.M. \& Woodward, F.I. 1989. Patterns in tree species richness as a test of the glacial extinction hypothesis. Nature 339: 699-701.

Allan, H.H. 1961. Flora of New Zealand. Vol. 1. Government Printer, Wellington.

Allen, R.B. 1993. A permanent plot method for monitoring changes in indigenous forests. Landcare Research, Christchurch.

Campbell, D.J. 1990. Changes in structure and composition of a New Zealand lowland forest inhabited by brushtail possums. Pac. Sci. 44: 277-296.

Cockayne, L. 1928. The vegetation of New Zealand. 2nd ed. Engelmann, Leipzig.

Coleman, J.D., Green, W.Q. \& Polson, J.G. 1985. Diet of brushtail possums over a pasture-alpine gradient in Westland, New Zealand. N. Z. J. Ecol. 8: 21-35.

$\rightarrow$ Condit, R., Hubbell, S.P. \& Foster, R.B. 1995. Mortality rates of 205 neotropical tree and shrub species and the impact of a severe drought. Ecol. Monogr. 65: 419-439.

Cowan, P.E. 1990. Brushtail possum. In: King, C.M. (ed.) The handbook of New Zealand mammals, pp. 69-98. Oxford University Press, Auckland.

Crawley, M.J. 1993. GLIM for ecologists. Blackwell, Oxford.

$\rightarrow$ Currie, D.J. \& Paquin, V. 1987. Large-scale biogeographical patterns of species richness of trees. Nature 329: 326-327.

Fitzgerald, A.E. 1976. Diet of the opossum Trichosurus vulpecula (Kerr) in the Orongorongo valley, Wellington, New Zealand, in relation to food availability. N.Z.J. Zool. 3: 399-419.

$\rightarrow$ Givnish, T.J. 1999. On the causes of gradients in tropical tree diversity. J. Ecol. 87: 193-210.

Grant, P.J. 1963. Forests and recent climatic history of the Huiarau Range: Urewera region, North Island. Trans. Royal Soc. N. Z. (Bot.) 2: 143-172.

Griffiths, G.A. \& McSaveney, M.J. 1983. Distribution of mean annual precipitation across some steepland regions of New Zealand. N. Z. J. Sci. 26: 197-209.

Hall, G.M.J. 1994. PC-DIAM: stem diameter data analysis. Landcare Research, Auckland.

Hall, G., Wiser, S., Allen, R., Moore, T., Beets, P. \& Goulding, C. 1998. Estimate of the carbon stored in New Zealand's indigenous forest and scrub vegetation for 1990. Landcare Research/New Zealand Forest Research Institute contract report (JNT9798/147) for the Ministry for the Environment, Wellington.

$\rightarrow$ Harcombe, P.A. 1987. Tree life tables. BioScience 37: 557568.

Harcombe, P.A., Allen, R.B., Wardle, J.A. \& Platt, K.H. 1998. Spatial and temporal patterns in stand structure, biomass, growth, and mortality in a monospecific Nothofagus solandri var. cliffortioides (Hook. f.) Poole forest in New Zealand. J. Sustain. For. 6: 313-345.

Harper, J.L. 1977. Population biology of plants. Academic Press, London.

Hosking, G.P. \& Hutcheson, J.A. 1988. Mountain beech (Nothofagus solandri var. cliffortioides) decline in the 
Kaweka Range, North Island, New Zealand. N. Z. J. Bot. 26: 393-400.

$\rightarrow$ Huston, M.A. 1999. Local processes and regional patterns: appropriate scales for understanding variation in the diversity of plants and animals. Oikos 86: 393-401.

King, C.M. (ed.) 1990. The handbook of New Zealand mammals. Oxford University Press, Auckland.

$\rightarrow$ Kohyama T. 1993. Size-structured tree populations in gapdynamic forest - the forest architecture hypothesis for the stable coexistence of species. J. Ecol. 81: 131-143.

Magurran, A.E. 1988. Ecological diversity and its measurement. Princeton University Press, Princeton, NJ.

$\rightarrow$ McCune, B. \& Cottam, G. 1985. The successional status of a southern Wisconsin oak woods. Ecology 66: 1270-1278.

McGlone, M.S. 1985. Plant biogeography and the late Cenozoic history of New Zealand. N. Z. J. Bot. 23: 723-749.

McGlone, M.S. 1988. History of the New Zealand vegetation. In: Huntley, B. \& Webb, T., III (eds.) Handbook of vegetation science, Vol. 7: Vegetation history, pp. 558599. Kluwer, Dordrecht.

$\rightarrow$ McGlone, M.S. 1996. When history matters: scale, time, climate and tree diversity. Global Ecol. Biogeogr. Lett. 5: 309-314.

Meads, M.J. 1976. Effects of opossum browsing on northern rata trees in the Orongorongo valley, Wellington, New Zealand. N. Z. J. Zool. 5: 127-139.

Meurk, C.D. 1995. Evergreen broadleaved forests of New Zealand and their bioclimatic definition. In: Box, E.O., Peet, R.K., Masuzawa, T., Yamada, I., Fujiwara, K. \& Maycock, P.F. (eds.) Vegetation science in forestry, pp. 151-197. Kluwer, Dordrecht.

Mueller-Dombois, D., Canfield, J., Holt, R.A. \& Buelow, G.P. 1983. Tree-group death in North American and Hawaiian forests: a pathological problem or a new problem for vegetation ecology? Phytocoenologia 11: 117-137.

Nakashizuka, T. 1991. Population dynamics of coniferous and broad-leaved trees in a Japanese temperate mixed forest. J. Veg. Sci. 2: 413-418.

Ogden, J., Lusk, C.H. \& Steel, M.G. 1993. Episodic mortality, forest decline and diversity in a dynamic landscape: Tongariro National Park, New Zealand. In: Huettl, R.F. \& Mueller-Dombois, D. (eds.) Forest decline in the Atlantic and Pacific Region, pp. 261-274. Springer-Verlag, Berlin.

Ogden, J., Stewart, G.H. \& Allen, R.B. 1996. Ecology of New Zealand Nothofagus forests. In: Veblen, T.T., Hill, R.S. \& Read, J. (eds.) The ecology and biogeography of Nothofagus forests, pp. 25-82. Yale University Press, New Haven, CT.

$\rightarrow$ Osawa, A. \& Allen, R.B. 1993. Allometric theory explains self-thinning relationships of mountain beech and red pine. Ecology 74: 1020-1032.

Owen, H.J. \& Norton, D.A. 1995. The diet of introduced brushtail possums Trichosurus vulpecula in a low-diversity New Zealand Nothofagus forest and possible implications for conservation management. Biol. Conserv. 71: 339-345.

Pekelharing, C.J. \& Reynolds, R.N. 1983. Distribution and abundance of browsing mammals in Westland National Park in 1978, and some observations on their impact on vegetation. N. Z. J. For. Sci. 13: 247-265.
Phillips, O.L. 1996. Long-term environmental change in tropical forests: increasing tree turnover. Environ. Conserv. 23: $235-248$.

$\rightarrow$ Phillips, O.L. \& Gentry, A.H. 1994. Increasing turnover through time in tropical forests. Science 263: 954-958.

$\rightarrow$ Phillips, O.L., Hall, P., Gentry, A.H., Sawyer, S. \& Vásquez, R. 1994. Dynamics and species richness of tropical forests. Proc. Natl. Acad. Sci. USA 91: 2805-2809.

Pickett, S.T.A. \& White, P.S. (eds.) 1985. The ecology of natural disturbance and patch dynamics. Academic Press, Orlando, FL.

Rogers, G.M. \& Leathwick, J.R. 1997. Factors predisposing forests to canopy collapse in the southern Ruahine Range, New Zealand. Biol. Conserv. 80: 325-338.

Rose, A.B., Pekelharing, C.J. \& Platt, K.H. 1992. Magnitude of canopy dieback and implications for conservation of southern rata-kamahi (Metrosideros umbellata-Weinmannia racemosa) forests, central Westland, New Zealand. N. Z. J. Ecol. 16: 23-32.

Shaw, W.B. 1983. Tropical cyclones: determinants of pattern and structure in New Zealand's indigenous forests. Pac. Sci. 37: 405-414.

$\rightarrow$ Sheil, D., Burslem, D.F.R.P. \& Alder, D. 1995. The interpretation and misinterpretation of mortality rate measures. $J$. Ecol. 83: 331-333.

Stewart, G.H. \& Burrows, L.E. 1989. The impact of white-tailed deer Odocoileus virginianus on regeneration in the coastal forests of Stewart Island, New Zealand. Biol. Conserv. 49: 275-293.

$\rightarrow$ Tilman, D., Wedin, D. \& Knops, J. 1996. Productivity and sustainability influenced by biodiversity in grassland ecosystems. Nature 379: 718-720.

Veblen, T.T. 1992. Regeneration dynamics. In: GlennLewin, D.C., Peet, R.K. \& Veblen, T.T. (eds.) Plant succession-theory and prediction, pp. 152-187. Chapman \& Hall, London.

Wardle, J.A. 1983. Disturbance and the ecology of beeches with emphasis on mountain beech. In: Silvester, W.B. \& Watt, V. (eds.) The future of Tongariro National Park beech forests, pp. 13-18. National Parks Series 24.

Wardle, J.A. 1984. The New Zealand beeches: ecology, utilisation and management. New Zealand Forest Service, Wellington.

Wardle, P. 1978. Regeneration status of some New Zealand conifers, with particular reference to Libocedrus bidwillii in Westland National Park. N. Z. J. Bot. 16: 471-477.

Wardle, P. 1991. Vegetation of New Zealand. Cambridge University Press, Cambridge.

Waring, R.H. \& Schlesinger, W.H. 1985. Forest ecosystems - concepts and management. Academic Press, Orlando, FL.

Wilkinson, L. 1997. SYSTAT ${ }^{\circledR}$ 7.0. SPSS. Chicago, IL.

Received 14 April 1998; Revision received 28 May 1999; Final revision received 28 October 1999; Accepted 29 June 1999. 